\title{
COMMUNITY RESILIENCE SCALE: ANALYSIS OF PSYCHOMETRIC ASPECTS AND RELATIONSHIPS WITH CRIMINAL VICTIMIZATION IN MEXICAN UNIVERSITY STUDENTS
}

\author{
Jose Ignacio Ruiz-Perez ${ }^{\mathrm{a}}\left({ }^{\circ}\right.$, Elsy Claudia Chan-Gamboa ${ }^{\mathrm{b} 1}(\mathbb{0}$, Luz \\ Anyela Morales-Quintero ${ }^{c} \mathbb{D}, \&$ Hiram Reyes-Sosa ${ }^{d}(\mathbb{D}) 2$
}

Universidad Nacional de Colombia, Bogotá, Colombia. ${ }^{\text {a }}$

Universidad de Guadalajara, Guadalajara, México. ${ }^{\mathrm{b}}$

Benemérita Universidad Autónoma de Puebla, Puebla, México. ${ }^{\mathrm{c}}$

Universidad Autónoma de Coahuila, Saltillo, México. ${ }^{\mathrm{d}}$

\begin{abstract}
The aim of the study was to determine the psychometric characteristics of the Community Resilience Scale (CRS, Ruiz, 2015) in two non-random samples (total $n=2500$ ) of university students from three Mexican cities. Method: The study was divided into 2 samples. Study 1 is a psychometric approach to determine the internal and factorial reliability of the Community Resilience Scale (CRS) in a sample of $n=1007$ Mexican university students. In Study 2, the sample was comprised of 1525 Mexican students from the same cities and institutions as those in sample 1. Results: In the first sample high internal reliability was found in the scale statistic, with three items being excluded. A factor solution comprising three dimensions was found: coping, humor and creativity, and collective-self-esteem, with suitable adjustment indices, replicated in a confirmatory analysis with the second sample. Moreover, it was found that a) the more victimization events, the lower the levels of community resilience, and b) the greater the collective humor, the lower the inclination to change place of residence and work. Conclusions: Results are discussed in relation to previous studies with the CRS and the impact of violence on the social fabric.
\end{abstract}

\section{Keywords}

community resilience, college students, criminal violence, communal coping, humor and creativity, collective self-esteem

\section{RESUMEN}

El objetivo del trabajo fue conocer el comportamiento psicométrico de la Escala de Resiliencia Comunitaria (ERC, Ruiz, 2015) en dos muestras no aleatorias (n total=2500) de estudiantes universitarios de tres ciudades mexicanas. Método: el estudio se dividió en dos muestras: estudio 1 es una aproximación psicométrica para conocer la fiabilidad interna y factorial de la Escala de Resiliencia Comunitaria (ERC) en una muestra de $n=1007$ estudiantes universitarios mexicanos. Estudio 2, integrado por una muestra de 1525 estudiantes mexicanos de las mismas ciudades e instituciones de la muestra 1. Resultados: Con la primera muestra, se halla una alta fiabilidad interna de la escala, excluyendo tres ítems. Se obtuvo una solución de tres factores -afrontamiento, humor y creatividad, y estima colectivos-, con adecuados índices de ajuste, replicados en un análisis confirmatorio con la segunda muestra. Además, se halló que a) a más sucesos criminales vividos, niveles más bajos de resiliencia comunitaria, y b) a más humor colectivo menos disposición a cambiar de lugar de residencia y trabajo. Conclusiones: Los resultados son discutidos con relación a estudios anteriores con la ERC y el impacto de la violencia sobre el tejido social.

Palabras clave

resiliencia comunitaria, estudiantes universitarios, violencia criminal, afrontamiento comunal, humor y creatividad, estima colectiva

\footnotetext{
${ }^{1}$ Correspondence about this article should be addresed to Elsy Claudia Chan-Gamboa: $\underline{\text { claudia.chan@cucs.udg.mx }}$

2 The authors of this article declare no conflict of interest
} 


\section{ESCALA DE RESILIENCIA COMUNITARIA: ANÁLISIS PSICOMÉTRICO Y DE RELACIONES CON VICTIMIZACIÓN CRIMINAL EN ESTUDIANTES UNIVERSITARIOS MEXICANOS}

\section{Introduction}

Community resilience refers to the health of the community, as a function of multiple, interdependent political, physical, cultural and psychological dynamics (Caye, 2011). In contrast, individual or family resilience focus on individual processes. For example, in a study on chain of life events in one hundred families living in extremely deprived neighborhoods, Davidson (2008) suggests that individual adaptation processes are supported by both formal and informal social resources. Along the same lines, Miller and Macintosh (1999) studied the influence of risk factors such as normative stress, discrimination and racial problems, as well as protective factors of racial socialization and social identity, on the educational performance of young African-Americans. Their findings indicated that the main source of socialization and protection from racism was the transmission of values, norms, morals and beliefs in the family and other settings, for succeeding in a racist environment. In this case, the family transmitted this set of beliefs and protective values that contributed to individual adjustment. Social support, which included promoting a sense of belonging to the community and society, as well as fostering communication with family, friends and peers, was one of the successful components of a program to promote the resilience of teachers and students in parts of Israel whose schools were attacked by bombs (Shacham, 2015). Other studies have identified the importance of the role of group support. For example, Bailey, Sharma and Jubin (2013) found that social support is one of the main variables with a positive direct and indirect effect on the level of resilience in African American women who had suffered the death of a son as a result of a firearm, measuring this resilience with the Connor Davidson Resilience Scale (CD-RISC, 2008). A recent study on resilience factors drawn from interviews with former American Prisoners of War (POW) in Vietnam, crime victims or families with a member with a serious disability or illness, showed that several of social factors are based on group support and/or the connection with affordable, effective institutional or health resources (Southwick \& Charney, 2014). In fact, one of the resilience factors they identified is social support, expressed in the case of the former combatants interviewed in the development of forms of communication between them, despite the restrictions imposed in the POW camps, or the optimism and humor that can be learned from observing models. Thus, social or community context is a main factor in relation to individual or mental health and resilience. 
Because of its impact on the lives of people and communities, it is worth exploring the components of resilience and its processes (Grotberg, 2001; in Pacheco-Mangas \& Palma-García, 2015), particularly community resilience, since it is possible to learn from these factors to create social services that promote and leverage these dynamics of resilience. Findings could provide individuals and communities, especially the youngest and most vulnerable, with opportunities to find a way out of a life and an environment perceived as chaotic and hopeless (Pivnick \& Villegas, 2000). Appropriate individual leadership (as shown by various experiences of creating services, partnerships, programs, etc.), may be the source of certain community resilience processes, although this does not require its members to be resilient at an individual level (Barrientos, 2003, in CarvalhoJuliano \& Mattar-Yunes, 2014). Individuals may, however, be positively influenced by this resilient environment, bearing out the age old social-psychological link between the individual and the environment (Páez, 2003).

In Latin America, there are few studies and scales addressing community resilience. One of the pioneering proposals for community resilience is put forward by Suárez Ojeda, La Jara and Marques (2007, in Carvalho-Juliano \& Mattar-Yunes, 2007; Suárez Ojeda, 2001). Suárez Ojeda considers core elements of community resilience to be: solidarity-communion of attitudes and feelings; adherence to common goals; social humor -the ability to maintain a positive outlook in adversity, making it possible to step back from the situation and to think and make decisions about it; cultural identityidentifying with customs, language, and a sense of belonging; and collective self-esteem, understood as the place where we live and the satisfaction of belonging to a group- and administrative honesty. These findings coincide at least partly with others that also identify humor (Garret, Parrish, Willians, Grayshield, Agahe-Portmant, Torres Rivera \& Maynard, 2014; Southwick \& Charney, 2014), solidarity towards disasters that affect communities (Ride \& Brethenton, 2011), and the appraisal of one's own cultural elements as components or factors of community resilience in American Indians (Garret et al, 2014; Waller \& Patterson, 2002). Such components of community resilience have also been found in young Mexicans with dual cultural heritage (Jackson, Wolven \& Aguilera, 2013), African Americans (Miller \& Macintosh, 1999) who cope with discrimination and racism, and Bhutanese refugees in the United States (Chase, 2012).

Suárez-Ojeda's community resilience model (2001) forms the conceptual basis of the Community Resilience Scale -CRS in English-, although the original scale was developed in the Spanish language -Escala de Resiliencia Comunitaria, ERC (Ruiz, 2015). The CRS has been used with Colombian university students in ten Colombian 
cities. A factorial analysis of fourteen of the sixteen items in the CRS yielded two dimensions: communal coping and collective self-esteem. The first was associated -both individually and aggregated by department-, with higher crime rates, especially homicide, extortion, drug-related crimes and illegal possession of weapons, which could be interpreted as the fact that the higher a society's crime rate, the more efforts it makes to address its problems. Conversely, higher crime rates were also associated with lower levels of collective esteem (Ruiz, 2015).

The overall objective of the first study in this research project was to determine the psychometric properties of the CRS in samples of a society such as Mexico, which has seen a rise in violent crime rates in recent years (Dudley, 2014 Cumplido, 2015; INEGI, 2015, 2018). An analysis of the contributing factors to the growth of this violence, although necessary, is beyond the scope of this paper (see, Cumplido, 2015). However, since it is worth asking how this violence impacts the fabric of Mexican society, specifically community resilience levels in Mexico, this study will analyze the convergent validity of the CRS with criminal victimization indicators. The second study seeks to confirm the factorial structure of the scale obtained in study 1.

\section{Methodology Study 1}

\section{Design and sample}

Study 1 is a psychometric approach to determine the internal and factorial reliability of the CRS in a sample of $n=1007$ Mexican university students from the cities of Puebla (39.9\%), Chihuahua $(\mathrm{n}=19,8 \%)$ and Guadalajara (40.4\%), drawn mainly from the bachelor's degree programs in criminology (22\%), psychology (23.5\%), law (17.1\%), medicine $(8.0 \%)$ and nursing $(7.5 \%) ; 68.9 \%$ of the respondents were enrolled in the first and second semesters. The average age was 19.7 years (95\% CI: 19.5 to 19.83); the majority were women $(65.1 \%)$ and single $(93.3 \%)$, obviously related to the youth of the sample members. The majority regarded themselves as middle class $(86.4 \%)$, followed by those who considered themselves to be lower-class (11.2\%) and upper-class (2.4\%).

Regarding their willingness to stay or change their place of residence and work, $41.9 \%$ came out in favor of remaining in the current place, $14.8 \%$ would change to another municipality or state in Mexico, and $43.3 \%$ would move to another country.

\section{Instruments}


As part of a broader study on perceived safety indicators, social fabric and criminal victimization, the following instruments were applied:

a. Community Resilience Scale (Ruiz, 2015). This scale consists of sixteen items with four response options in the Likert-type format, in each of which respondents show their degree of agreement with each of the claims-items on the scale, from 1 (totally disagree) to 4 (totally agree). Items include: "In my municipality, the community ..." "Deals with everyday problems with good humor", and "Can laugh at their problems and that helps overcome them." The internal reliability of the scale in the original study was .87 .

b. List of Criminal Victimization Events (Ruiz \& Turcios, 2009). This is a list of sixteen types of criminal victimization. Respondents must indicate whether these incidents have occurred in the six months prior to answering the survey. These crimes were grouped into five categories, on the basis of an analysis of hierarchical classification (Chan-Gamboa, Morales-Quintero, Ruíz \& VacaCortés, 2017): 1) killings and kidnappings, 2) sexual crimes and harassment, 3) own and family members' road injuries, 4) robbery and persecution and 5) extortion and obscene calls.

c. Willingness to change one's place of residence and work questionnaire. Participants were asked to choose one of the following options: "Stay in the same city", "change town or state" or "change country".

d. Socio-demographic and academic data questionnaire. This questionnaire was designed for the purposes of the study and includes queries on age, sex, socioeconomic class (low, medium, high), degree course and university semester enrolled in at the time of answering the survey.

\section{Procedure}

The study was conducted online. The link was sent to students from the three universities covered in the study after the paperwork had been carried out and the respective academic permits had been obtained. The survey entailed first obtaining the subject's agreement (informed consent) to answer the scale.

\section{Data Analysis}

The SPSS v.18 program was used to obtain descriptive statistics of the sample in the sociodemographic and educational variables related to the CRS; calculating the 
Cronbach coefficient to determine its internal reliability. The Factor 10.0.3 program with a parallel analysis of the CRS was calculated together with a factorial analysis of main components, which includes several adjustment indices. Pearson correlations were calculated between CRS dimensions and victimization scores. Although the sample is not representative, the ecological validity of student samples has been proven to describe the psychosocial phenomena that affect the societies from which the samples have been drawn (Páez \& Vergara, 2000).

\section{Results}

The internal reliability of the scale was .88 , with items 9,10 and 11 being recoded (see Table 1, with the homogeneity coefficients for items 9, 10 and 11 in brackets before recoding). The low item-scale correlation for items nine and ten prompted the decision to discard them in subsequent analyses.

\begin{tabular}{|c|c|c|c|c|c|c|}
\hline \multicolumn{7}{|c|}{$\begin{array}{l}\text { Table } 1 \\
\text { Distribution of responses (\%) in each item of the CRS, Homogeneity Index and Cronbach's } \\
\text { alpha of the scale extracting each item }\end{array}$} \\
\hline ITEM & Totally disagree & Disagree & Agree & Totally agree & $\mathrm{IH}$ & $\alpha$ \\
\hline Item 1 & 5.4 & 8.6 & 35.1 & 50.8 & .557 & .874 \\
\hline Item 2 & 4.0 & 13.9 & 39.3 & 42.6 & .611 & .871 \\
\hline Item 3 & 6.9 & 21.7 & 49.9 & 21,5 & .484 & .877 \\
\hline Item 4 & 6.1 & 28.3 & 43.8 & 21,8 & .622 & .871 \\
\hline Item 5 & 6.8 & 18.2 & 46.4 & 28,6 & .566 & .873 \\
\hline Item 6 & 3.9 & 18.1 & 53.7 & 24,4 & .635 & .871 \\
\hline Item 7 & 5.6 & 19.5 & 47.9 & 27,1 & .619 & .871 \\
\hline Item 8 & 6.72 & 23.8 & 45.0 & 24,5 & .620 & .871 \\
\hline Item 9 & 10 & 34.2 & 34.7 & 21,1 & $.081(-.104)$ & .894 \\
\hline Item 10 & 42.4 & 36.3 & 17 & 4.3 & $.185(-.175)$ & .889 \\
\hline Item 11 & 13.9 & 26.2 & 38.5 & 21.4 & $.469(-.414)$ & .878 \\
\hline Item 12 & 8.5 & 25.4 & 46.6 & 19.5 & .619 & .871 \\
\hline Item 13 & 3.3 & 10.6 & 35.6 & 50.5 & .566 & .873 \\
\hline Item 14 & 4.2 & 19.2 & 52.7 & 23.9 & .685 & .869 \\
\hline Item 15 & 5.6 & 15.2 & 46.9 & 32.3 & .656 & .869 \\
\hline Item 16 & 4.9 & 13.8 & 47.7 & 33.7 & .596 & .872 \\
\hline
\end{tabular}

The FACTOR program was subsequently used to undertake a parallel analysis (Lloret-Segura, Ferreres-Traver, Hernández-Baeza \& Tomás Marco, 2014), which focuses on the number of factors to be explored, yielding an indication with three factors. The same program was used to conduct an analysis of the principal components and varimax rotation of the CRS items (excluding 9 and 10), having previously obtained satisfactory indices in the KMO and the Barlett sphericity test (see Table 2). This table identifies three fairly clear factors as regards their content, although item 11 has low, similar charges in two factors, as a result of which a new factorial analysis was undertaken, excluding item 11 (see Table 3).

Table 2 


\begin{tabular}{|c|c|c|c|}
\hline ITEMS & Factor 1 & Factor 2 & Factor 3 \\
\hline 1-You feel proud of the culture you live in: dance, music, theater, art. & & .786 & \\
\hline 2-You highly value your history and group identity & & .796 & \\
\hline 3-You are able to deal with everyday problems with a sense of humor. & & & 618 \\
\hline 4-You trust your abilities as a community to resolve your difficulties & & .312 & .537 \\
\hline 5-You are happy to live in your community & & .374 & 371 \\
\hline $\begin{array}{l}\text { 6-You have the creativity required to progress despite the chaos and } \\
\text { difficulties }\end{array}$ & 371 & & 63 \\
\hline 7-You can laugh at your problems and that helps you overcome them & & & .764 \\
\hline 8-You act for the collective good rather than the benefit of a few & 412 & & 419 \\
\hline 11 You take symbols such as the flag and anthem very seriously. & .351 & .309 & \\
\hline $\begin{array}{l}\text { 12-You think how to solve problems together rather than waiting for } \\
\text { them to be solved from the outside }\end{array}$ & .593 & .51 & \\
\hline 13- You are proud of the local climate, landscape and natural riches & .363 & & .334 \\
\hline $\begin{array}{l}\text { 14-You know how to look for legitimate alternatives to solve your } \\
\text { problems }\end{array}$ & 713 & & \\
\hline $\begin{array}{l}\text { 15-You are able to see what can be improved, rather than blaming others } \\
\text { for problems }\end{array}$ & 796 & & \\
\hline $\begin{array}{l}\text { 16-You realize that other countries provide knowledge that contributes } \\
\text { to progress }\end{array}$ & 654 & & \\
\hline $\begin{array}{l}\text { Eigenvalue: } \\
\% \text { Variance: }\end{array}$ & $\begin{array}{c}6.239 \\
44.50 \%\end{array}$ & $\begin{array}{l}1.258 \\
8.98 \%\end{array}$ & $\begin{array}{l}1.165 \\
8.32 \%\end{array}$ \\
\hline Cronbach's alpha: & .763 & .779 & .723 \\
\hline
\end{tabular}

KMO: .913 Bartlett: $6140.4 * * * *$, gl:91

This factorial solution yields clearer factors as regards the content of the items and distinguishes between them. The first refers to community coping, which involves the search for solutions at the group level; the second factor identifies social humor and creativity as a salient aspect of community resilience, while the third axis is related to collective self-esteem in relation to positively valuing the respondent's history, cultural identity and natural environment.

The FACTOR program provides a series of adjustment indices of the factorial model applied through parallel analysis. Table 4 shows these adjustment indices for each of the factorial solutions analyzed (Tables 2 and 3 ) and one can see that these indices are still fairly acceptable in both solutions. They are better when items 11,9 , and 10 are excluded from the analysis. The internal reliability of the scale when these three items were removed was .90 .

Table 3

Principal component analysis of CRS with 13 items

\begin{tabular}{lll}
\hline ITEM & $\begin{array}{l}\text { Factor } \\
\text { Factor }\end{array}$ & $\begin{array}{l}\text { Factor } \\
3\end{array}$ \\
\hline 1-You feel proud of the culture you live in: dance, music, theater, art. & & .995 \\
2-You highly value your history and group identity & .959 \\
3-You are able to deal with everyday problems with a sense of humor. & .758 \\
4-You trust your abilities as a community to resolve your difficulties & .583 \\
5-You are happy to live in your community & .323 & .315 \\
6-You have the creativity to advance amid the chaos and difficulties & .684 \\
7-You can laugh at your problems and that helps you overcome them & .919 \\
8-You act for the collective good, rather than the benefit of a few & .355 \\
12-You think how to solve problems together rather than waiting for them & .605 & \\
to be solved from the outside & & \\
\hline
\end{tabular}




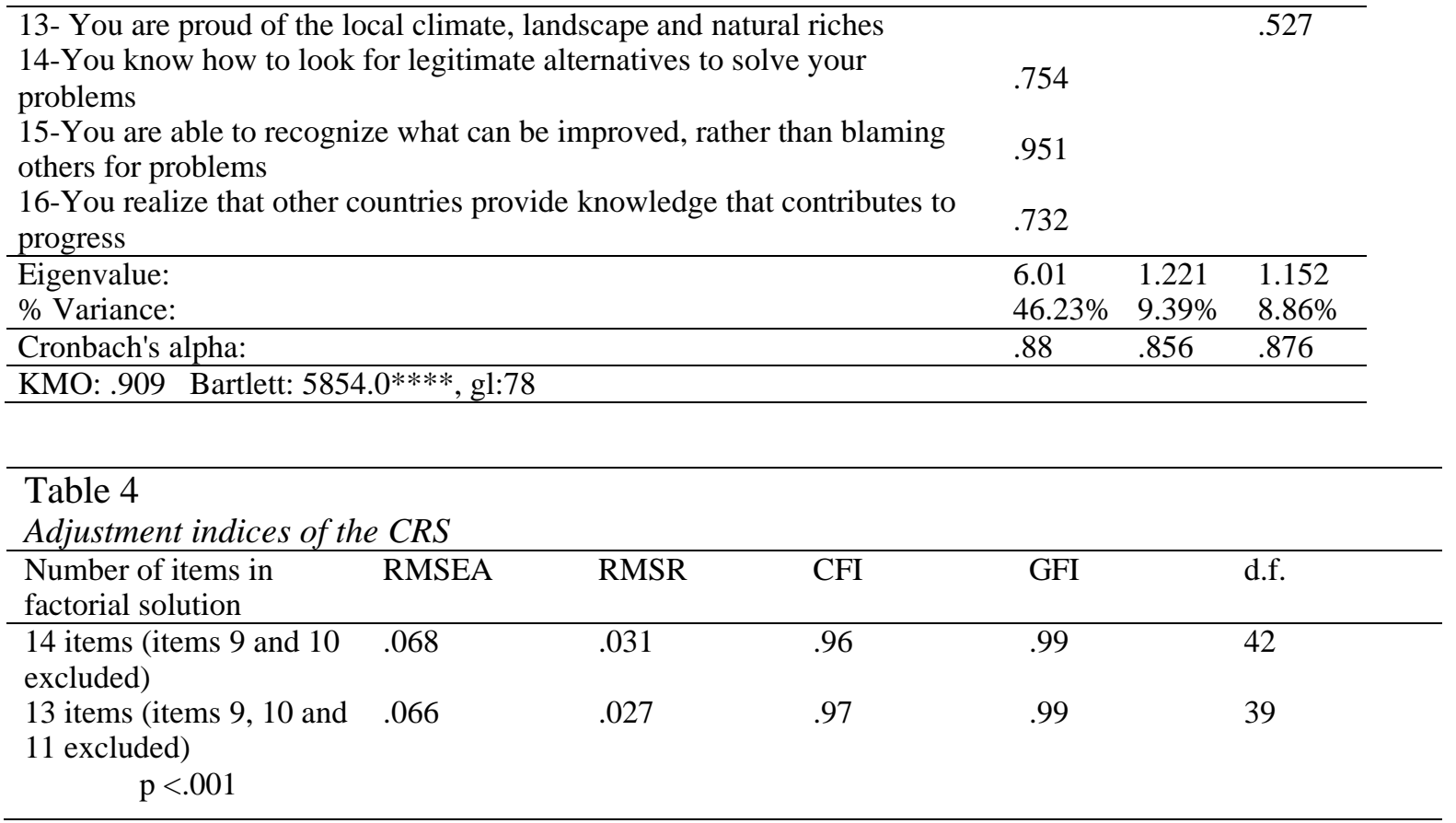

Given these results, the next step was to confirm the three-dimensional structure for which a second study was conducted.

\section{Methodology Study 2}

The sample comprised 1525 Mexican students from the same cities and institutions as those in sample 1. The mean age was 19.67 (CI 95\% and from 19.55 to 19.79), with $62.5 \%$ women, $94.4 \%$ single, studying degree courses such as criminology (22.4\%), law (18.1\%), psychology (25.8\%), medicine (6.1\%) and nursing (5.8\%). Most were enrolled in their first or second semester (68.6\% of subjects), and the majority described themselves as middle class $(86.1 \%)$. There were no significant differences between the samples in study 1 and 2 in any socio-demographic or academic variable, including city of residence, or inclination to stay/move from the current place of residence.

The instrument used was similar to the one in Study 1, limiting the confirmatory factor to the thirteen items retained in the preceding analysis (Table 3). This instrument was also given online, and once again included the informed consent process. The analyses were carried out using the MPlus v. 6 program.

\section{Results}

On the basis of the results of Study 1, a three-dimensional model of CRS was proposed, which is reflected in Figure 1 and yields coefficients with suitable coefficients: 
RMSEA: .077 (IC 90\% .074 - .081; CFI: .928; TLI: .922, RMSR: .052, with Chi2: $15.413, \mathrm{p}<.0001$.

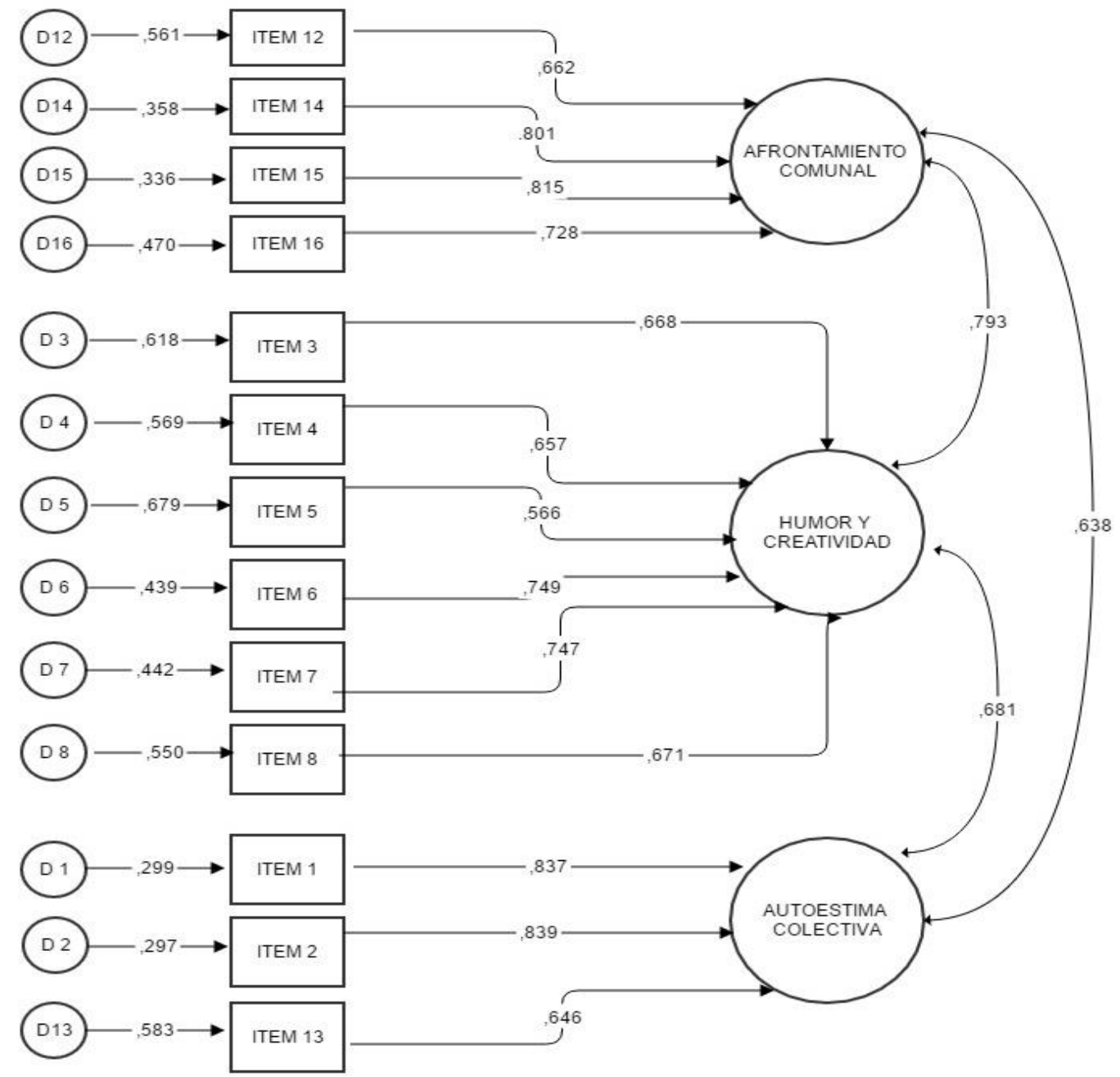

Figure 1. Confirmatory analysis of the CRS based on a three-dimensional model (Extraction method: maximum probability; d.f.: 39). Note: The concepts in the circles mean in English: Community coping, Social humor and creativity, and Collective self-esteem.

Lastly, some scores for each subject were calculated for each factor of community resilience (community coping, humor and creativity, and collective self-esteem), combining the samples of the two studies while discarding any items with similar low loads in more than one factor. These scores were correlated by the Pearson coefficient with victimization indicators and the inclination to change or remain in the place of residence and work indicator (see Table 5). The results show that in general, greater experience of crime is associated with perceiving fewer aspects of community resilience in one's environment. Considering the size of the correlation coefficients, the negative impact of crime is higher in the collective self-esteem component. Also, the higher the crime rate, the greater the inclination to change one's place of residence, yet the greater the social humor and collective self-esteem, the less inclination there was to make these changes (communal coping does not seem to have any link with this willingness). Finally, 
and in keeping with previous factorial results, a high direct correlation was found between the three pillars of community resilience.

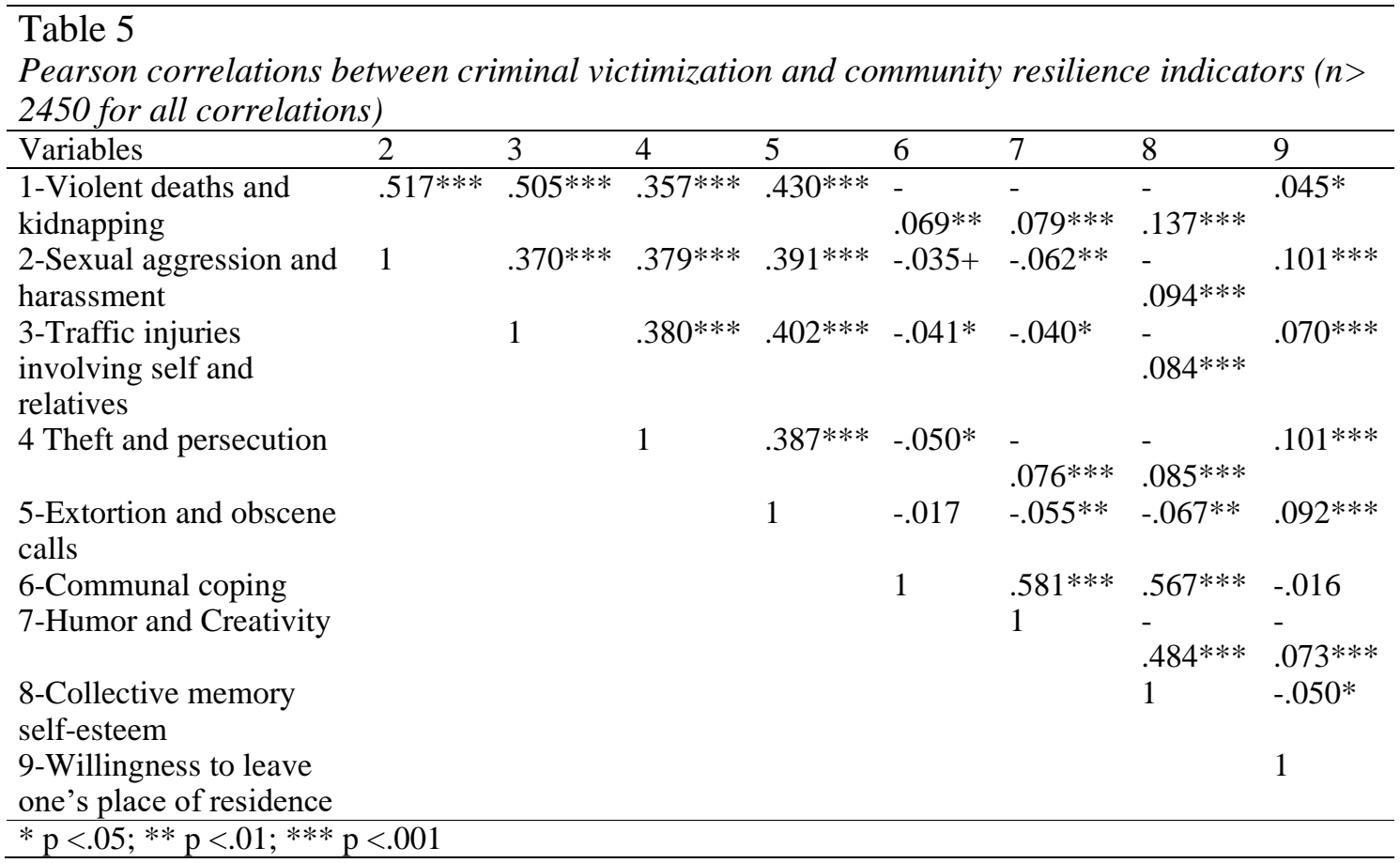

\section{Discussion and Conclusions}

As Carvalho-Juliano \& Mattar-Yunes (2007) have pointed out for decades, Latin American societies have been exposed to major natural disasters and/or socio-political and economic processes of social inequality in the distribution of wealth. According to the OECD (2014), half the Mexican population lives in poverty. Moreover, recent years have seen high crime rates, often involving criminal drug trafficking organizations, which have led to several South American countries and cities being ranked among those with the greatest violence (Dudley, 2014). However, one must also recognize the important processes of democratization that have recently been experienced by several of these Latin American societies; such as the reduction of crime rates in some of them and even the dismantling or demobilization of armed groups, as has recently been the case in Colombia.

How can one strengthen or contribute to the resilience of human societies, and the communities that form part of them, in the face of economic crises, crime and natural disasters? Perhaps part of the answer lies in deepening knowledge about how the components and processes of the social fabric, such as community resilience, operate. It is therefore necessary to have instruments to measure these components, and within this framework, the psychometric results are presented for the Community Resilience Scale, 
which was originally standardized with Colombian samples (Ruiz, 2015), and in this study, used with samples of Mexican students.

The scale showed high internal reliability, ranging between 0.88 and 0.90 , for all the items or a 13-item proposal, respectively. At the factorial level (Study 1), a threedimensional structure was initially found and subsequently confirmed (Study 2), which differentiates between community coping - such as the willingness and initiative of the community to seek solutions to their problems-; collective self-esteem -pride in their history and cultural elements; and humor and creativity. The link between humor and creativity confirms the findings of Suárez Ojeda and colleagues $(2001,2007)$, that humor makes it possible, both individually and collectively, to take a step back from problems, see them differently and increase the chances of finding solutions or alleviating the situation. In this respect, humor could be linked to the capacity for the cognitive reevaluation of situations, which is also a factor of resilience, according to some authors (Bayley et al, 2013; Southwick \& Charney, 2014). Note, these last authors included creativity as a resilience factor in their list of components or dimensions of resilience.

On the other hand, experiences of criminal victimization are associated with a decrease in the perceived resilience of the community, reflected in lower collective selfesteem and a greater willingness to leave the city where the respondent lives. In this regard, the impact between victimization and collective self-esteem is similar to that found in the Colombian students (Ruiz, 2015). However, in the latter, higher crime rates, measured through police arrests and self-reported victimization, were associated with greater communal coping; in other words, an inverse correlation to that found in the students in the present study. This could be because the Colombian study covered 32 cities with highly variable population sizes, ranging from nearly 13,000 inhabitants in the department of Guainia to more than 7,900,000 in Bogota $^{3}$, according to estimates for 2016. These variations could be related to very different weather conditions, urban infrastructure, modes of production, human development and daily exposure to the violence of the Colombian armed conflict between regions, where communities often had to learn to survive and carry on with their everyday lives despite various adverse circumstances; whereas the respondents in this study come from medium-sized cities, with populations of approximately 878,000 (Chihuahua), 1,500,000 (Puebla) and

\footnotetext{
${ }^{3}$ Retrieved from https://www.minsalud.gov.co/Documentos\%20y\%20Publicaciones/An\%C3\%A1lisis\%20de\%20situaci\% C3\%B3n\%20de\%20salud\%20por\%20regiones.pdf on June 25, 2016.
} 
$4,600,00$ (Guadalajara) in $2015^{4}$. As for the inclination to stay or change one's place of residence being associated with lower collective self-esteem, this study confirms one of the psychosocial effects of collective violence and crime, the weakening of the social fabric through residents' displacement to safer places, correlative to a diminished sense of community. This result has previously been found in research on the impact of fear of crime (Skogan \& Maxfield, 1981, in Ruiz, 2014).

Having a scale like the Community Resilience Scale, with its high reliability and solid factorial structure, is crucial for enabling municipal organizations, as well as academic institutions and civil organizations, to undertake social diagnoses that will guide efforts to implement effective interventions and public policies in the tasks of reconstructing the social fabric, actions by police forces and community initiatives in Mexico. This is important for a country with a high perception of victimization and insecurity, where there is an estimated rate of 29,746 victims over the age of 18 for every 100,000 inhabitants (35,500 in Chihuahua, 37,900 in Guadalajara and 40,600 in Puebla), which are rates above the national average (INEGI, 2018). Moreover, it is estimated that $64.5 \%$ of the population over the age of 18 regard insecurity and crime as the main problems in the country (INEGI, 2018).

Another striking feature is the different factorial structure of the scales found among the Colombian data, with two dimensions involving communal coping and collective self-esteem, while the present study reveals a third dimension, namely humor and creativity. This result, together with the psychometric behavior of certain items that have yet to be refined and adjusted, and in relation to the debate on which components, processes and results are essential to community resilience, suggests a need for future research that will permit the development of conceptually solid, psychometrically robust and socially useful instruments to measure this type of social construct., Also, further study with non-university students and in rural areas of other regions of Mexico is needed. Areas with higher violence or unemployment rates could affect psychosocial dynamics and structure. These three factors are key indicators that should be taken into account in programs and actions designed to strengthen communities and improve their relationship with criminal victimization.

\footnotetext{
${ }^{4}$ Data extracted from http://www.cuentame.inegi.org.mx/ on June 25, 2016.
} 


\section{References}

Bailey, A., Sharma, M. \& Jubin, M. (2013). The mediating role of social support, cognitive appraisal, and quality health care in black mothers' stress-resilience process following loss to gun violence. Violence and Victims, 28(2), 233-247. https://doi.org/10.1891/0886-6708.11-00151

Carvalho-Juliano, M.A. \& Mattar Yunes, M.A. (2014). Reflections on the social support network as a mechanism for the protection and promotion of resilience. Ambiente et Sociedade, 18(3), 135-152. https://doi.org/10.1590/S1414753X2014000300009

Caye, M. (2011). Formative Research and Community Resilience: A Case of Under Addressed Youth Problem Gambling. New England: Antioch University.

Chan-Gamboa, E. C., Morales-Quintero, L. A., Ruiz-Pérez, J. I. \& Vaca-Cortés, J. (2017). Factores sociodemográficos asociados a la victimización delictiva en estudiantes universitarios de tres ciudades mexicanas. Pensamiento Psicológico, 15(2), 93107. https://doi.org/10.11144/Javerianacali.PPSI15-2.fsav

Cumplido, M.A. (2015). Evolución del crimen organizado en México: más allá del narcotráfico. Documento marco. Madrid: Instituto Español de Estudios Estratégicos.

Davidson, R. (2008). More than 'Just Coping': The Antecedents and Dynamics of Resilience in a Qualitative Longitudinal Study. Social Policy \& Society, 8(1), 115125. https://doi.org/10.1017/S1474746408004636

Dudley, S. (2014). Evolución criminal y violencia en Latinoamérica y el Caribe. InsightCrime, June 26, 2014. Retrieved from http://es.insightcrime.org/analisis/evolucion-criminal-violencia-latinoamericacaribe.

Garret, M.T., Parrish, M., Willians, C., Grayshield, Lagahe-Portmant, T. A., TorresRivera, E. \& Maynard, F. (2014). Invited commentary: Fostering resilience among native American youth through therapeutic intervention. Journal of Youth Adolescence, 43, 470-490. https://doi.org/10.1007/s10964-013-0020-8

Instituto Nacional de Estadística y Geografía (INEGI) (2015). Encuesta Nacional de Victimización y Percepción sobre Seguridad Pública (ENVIPE) 2014. Available at:

http://www.inegi.org.mx/saladeprensa/boletines/2015/especiales/especiales2015 _09 7.pdf.

Instituto Nacional de Estadística y Geografía (INEGI) (2018). Encuesta Nacional de Victimización y Percepción sobre Seguridad Pública (ENVIPE) 2017. Available at:

https://www.inegi.org.mx/contenidos/programas/envipe/2018/doc/envipe2018_p resentacion_nacional.pdf

Jackson, K.F., Wolven, T. \& Aguilera, K. (2013). Mixed resilience: a study of multiethnic Mexican American stress and coping in Arizona. Family Relations, 62(1), 212225. https://doi.org/10.1111/j.1741-3729.2012.00755.x

Lloret-Segura, S., Ferreres-Traver, A., Hernández, A. \& Tomás-Marco, I. (2014).El análisis factorial de los ítems: una guía práctica, revisada y actualizada. Anales dePsicología, 30(3), 1131-1160. http://dx.doi.org/10.6018/analesps.30.3.199361

Miller, D. \& MacIntosh, R. (1999). Promoting resilience in urban African American adolescents: racial socialization and identity as protective factors. Social Work Research, 23(3), 159-169.

Organización para la Cooperación y el Desarrollo Económicos (OCDE) (2014). Estudio Económico de México 2015. Available at: http://www.oecd.org/mexico/presentacion-del-estudio-economico-de-mexico2015.htm. 
Pacheco-Mangas, J. \& Palma García, M.O. (2015). La resiliencia en Servicios Sociales Comunitarios: un abordaje desde la perspectiva de los profesionales. Azarbe: Revista Internacional de Trabajo Social y Bienestar, 4, 29-38.

Páez, D. \& Vergara, A.I. (2000). Theoretical and methodological aspects of cross-cultural research. Psicothema, 12(1): 1-5.

Páez, D. (2003). Objeto de estudio de la psicología social. En D. Páez, I. Fernández, S. Ubillos, E. Zubieta (Eds.). Psicología social, Cultura y Educación (pp. 3-25). Madrid: Pearson-Prentice Hall.

Pivnick, A. \& Villegas, N. (2000). Resilience and risk: childhood and uncertainty in the aids epidemic. Culture, Medicine and Psychiatry, 24, 101-136. https://doi.org/10.1023/A:100557421257

Ride, A. \& Bretherton, D. (2011). Community resilience in natural disasters. New York: Palgrave Macmillan. (Briefly Noted).

Ruiz, J.I. (2014). Psicología Social y Justicia. Bogotá: Universidad Nacional de Colombia-Colegio Colombiano de Psicólogos.

Ruiz, J.I. (2015). Resiliencia comunitaria: propuesta de una escala y su relación con indicadores de violencia criminal. Pensamiento Psicológico, 13(1),119-135.

Ruiz, J.I. \& Turcios, L.A. (2009). Percepción de seguridad, victimización y cultura ciudadana: sus relaciones en cinco contextos iberoamericanos. Pensamiento Psicológico, 6(13), 193-202

Shacham, M. (2015). Suddenly-war intervention program for enhancing teachers and children's resilience following war. Revista de Cercetare si Interventie Sociala, 48. 60-68.

Southwick, S.M. \& Charney, D.S. (2014). Resilience: the science of mastering life's greatest challenges. Nueva York: Cambridge University Press.

Suárez-Ojeda, E. N. (2001). Una concepción latinoamericana: la resiliencia comunitaria. In A. Melillo, E. N. Suárez-Ojeda (Coord.). Resiliencia: descubriendo las propias fortalezas, (pp. 67-82). Buenos Aires: Paidós.

Suáres-Ojeda, E.N., La Jara, A. \& Marques, C. (2007). Resiliência Comunitária. In: C. Hoch, \& S. Rocca (Eds.), Sofrimento, Resiliência e Fé-Implicações para as relações de cuidado (pp. 97). São Leopoldo: Editora Sinodal.

Waller, M.A. \& Patterson, S. (2002). Natural helping and resilience in a Diné (Navajo) Community. Families in Society, 83(1), 73-84. https://doi.org/10.1606/1044$\underline{3894.46}$ 